DOI https://doi.org/10.18551/rjoas.2017-12.19

\title{
PERFORMANCE-BASED BUDGETING AS THE REALIZATION OF FINANCIAL MANAGEMENT REFORMATION IN MALANG CITY
}

\author{
Sabilana Arsidna*, Muluk M.R. Khairul, Setyowati Endah \\ Public Administration Department, Faculty of Administrative Science, \\ University of Brawijaya, Indonesia \\ *E-mail: arsidna.sabilana@gmail.com
}

\begin{abstract}
The development of performance-based budgeting is a challenging program to adminster, such as the issues experienced by Malang city. Thus, it is considered necessary to conduct a thorough analysis on the performance-based budgeting conducted by Malang. This study employed a descriptive qualitative study. The result of this study shows that the budgeting conducted by Malang city has been done on time and integratively as an attempt to realize the budgeting based on performance. Some parameters were used to implement this program, including minimum standard service, minimum price per item, and performance indicator. However, Malang city has not yet owned a standard budgeting analysis. Factors that influence the implementation of performance-based budgeting are environmental factors (social, culture, economy, politics), resource planning, the advancement of the system, the development of information and technology, and funding. It is expected that the central government distribute the funding on time in order to help the local governemnt of Malang city to design the budgeting plan within the scheduled time. The design of the standard budgeting analysis (ASB) should be well-designed to support the implementation of the performance-based budgeting.
\end{abstract}

\section{KEY WORDS}

Performance-based budgeting, local government, financial indicators, management, reformation.

Riyadi (2003, p.8) stated that the regional development planning is a process to design the steps and procedure that involve various elements in order to optimally utilize and allocate the resources to improve the social welfare of certain area within certain period of time.

One of the major local resouces is the financial resource. Financial resource is the motor that drives the regional development. Financial resource should be precisely-managed in order to reach the goals of the decentralization. Therefore, a reformation on the financial management of regional government is a crucial step to reach the goal of the decentralization and to create consistent and consequent local governance.

Financial reformation requires a thorough planning and approach to the system of the performance budgeting, and more emphasize on the responsibility, to focus more on on the output and outcome rather than focusing only on the input (Halim, 2007, p.5). Performancebased budgeting demands synchronization between the programs and the fund. Hence, the fund withdrawal can only be done to fund the programs that have been previously planned. In addition, financial allocations in the regional government are intergrated with the reports of the programs which allow the regional government to optimally, economically, effectively and efficiently use the fund.

The consistency on the implementation of the performance-based budgeting that is not supported by precise methodological approach in designing the indicators of the performance is also being questioned. In fact, the government puts mainly focus only on the brand of the program and its implementation. Targets or the goals of the program are in the form of description or qualitative data which make the parameters and the indicators less measurable. 
The main issue in the planning of the performance-based budgeting is society's mindest on the traditional budgeting (Rahayu, 2007). The reformation on the regional government financial management as stated by Halim (2007, p.5) requires a shift from the traditional budget to the performance budget. This change should be followed by some other modifications within the system such as technical modification, change of certain formats, and the shifting of the paradigm. However, the regional government has not yet successfully brought the change. Consequently, the format used in the system has been suitable with the performance-based budgeting, yet the mindset remains the same.

\section{LITERATURE REVIEW}

The Plan of Suburban Area Development. Bryant (1982, p.310) stated that the planning step is a political step that involves various interests which are not comprehensive interests in which planners and politicians shold participate in the process. Meanwhile, Slagian (1978, p.2) defined development as an effort or a set of attempts to consciously grow and bring changes to a certain society, country and a governance to create a more modern life for the advancement of the nation building.

The definition of local area development shold be seen from the elements within it that include the planning, the development and the area as explained in the previous explanation. Riyadi (2003, p.1) stated that local area development plan refers to a system that is created upon some elements including the planning, development and the area itself. Each of the element should be divergently analyzed before a convergent conclusion can be drawn to determine a complete definition on the matter.

Affandi Andwar and Setia Hadi define the local area development as a process or step to direct the development plan in a certain area that requires an interaction between the human resource and other resources including the natural resource and environment through an adequate investment. (Prisma, 1996 p.49).

Factors that influence the success of the local area development program as mentioned by Riyadi (2003, p.15-39) include: Environmental Factors (Social, Culture, Economy); Politics (Human resource, The system, The advancement of information and technology, Funding).

The Reformation of the Financial Management in the Regional Government. There are at least six modifications on the management of the regional budget as mentioned by Halim (2007: 5-6), which are:

- A shift from the use of vertical accountability to horizontal accountability

- A shift from the use of traditional budge to performance budget

- A shift from financial control and audit to financial control and audit and performance

- Implementation of value for money concept

- The implementation of central accountability concept

- Modifications on the government's accounting system

Regional government Budget. Regional government budget is a calculation of income and expenses. Formally, regional government budget is called Anggaran Pendapatan dan Belanja Daerah (APBD) which is the plan to use the fund by the regional government that is legalized by the House of the Representatives. $A P B D$ is the realization of the financial management within a year. $A P B D$ is closely related to the society since every public service requires fund. Hence, $A P B D$ should be legalized by the House of Local Representatives (DPRD) (Subekan, 2012, p.94).

There have been a number of approaches used in designing the budget. The approaches can be determined from the output/display of the budget itself as mentioned by Nordiawan (2006, p.53), which are: Traditional Approach, Performance Approach, Approach through Planning, Programming, and Budgeting System (PPBS), Zero-Based Budgeting (ZBB).

According to Tjandra (2006, p.43), performance-based budgeting is a systematic approach to improve government's responsibility to the tax payers by integrating the funding to the performance and production. 


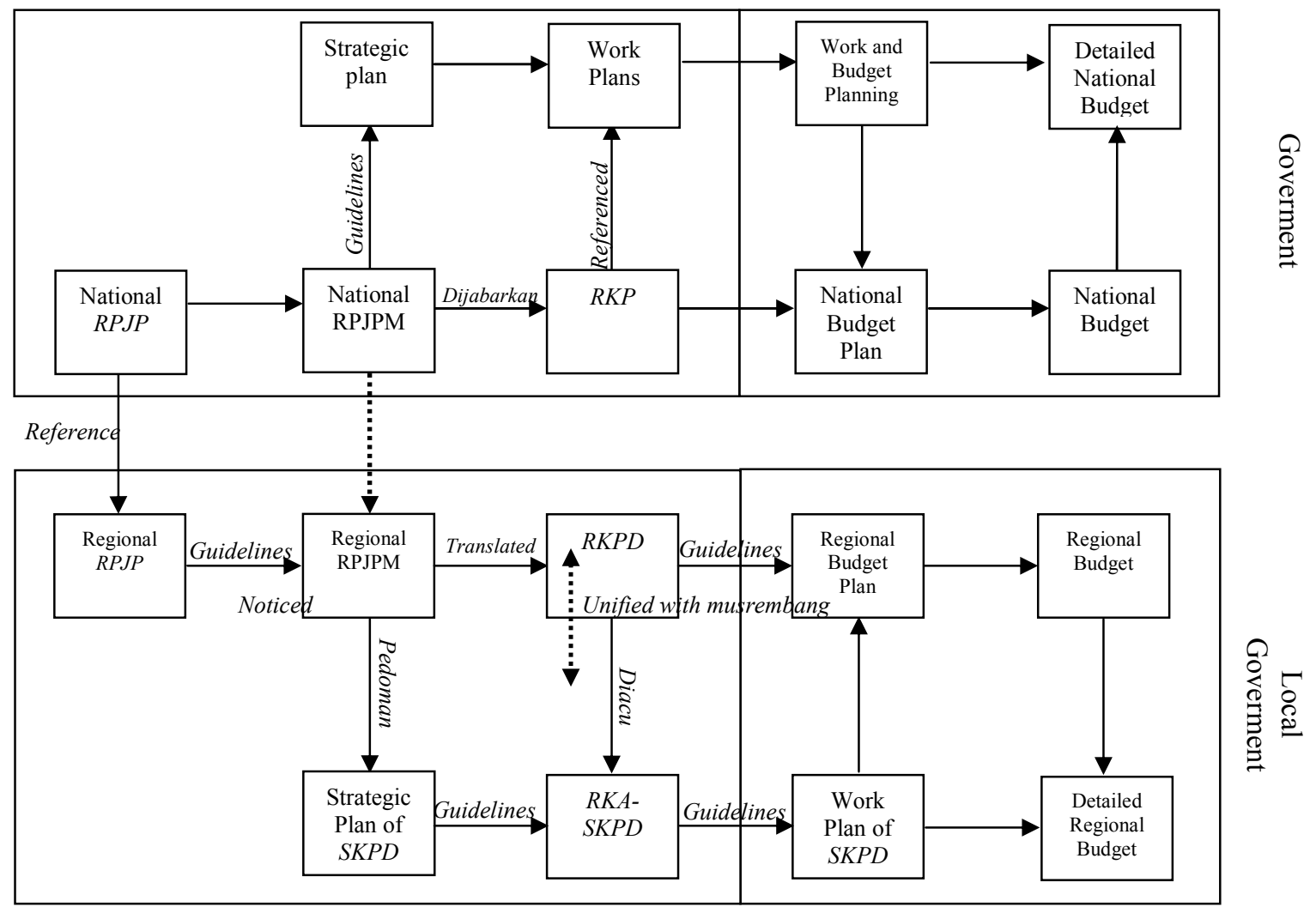

Figure 1 - Procedure of Budget Planning

Suhandak and Suhandak (2007, p.111) explained some indicators that measure the success of the performance-based budgeting, they are; (a) Standar Pelayanan Minimal (SPM) or the minimum standard service; (b) Indikator Kinerja or indicators of the performance; (c) Analisis Standar Belanja (ASB) or the analysis of the standard expenses; and (d) Standar Satuan Harga (SSH) or standard price per item.

Futhermore, the steps in designing $A P B D$ are written in the Regulation of the Ministry of Internal Affairs number 59 of 2007 as follow:

- Penyusunan Rencana Kerja Pemerintah Daerah (RKPD) or designing the regional government programs

- Penyusunan rancangan Kebijakan Umum APBD (KUA) dan rancangan Prioritas Plafon Anggaran Sementara (PPAS) or designing the public policies and the temporary funding priorities

- Penetapan Pedoman Penyusunan RKA-SKPD oleh Kepala Daerah or determining the guidelines of $R K A-S K P D$ by the head of the regional government.

- Penyusunan Rencana Kerja dan Angaran SKPD (RKA-SKPD) or designing the RKASKPD

- Penyiapan Raperda APBD or preparing the meeting

- Pembahasan Raperda APBD or discussing the meeting

- Pembahasan Raperda APBD oleh DPRD or discussion on the budget by the DPRD

- Penyusunan Rancangan Peraturan Kepala Daerah tentang penjabaran APBD or the explanation on the budgeting

- Evaluasi Raperda APBD dan Rancangan Peraturan Kepala Daerah tentang Penjabaran $A P B D$ or the evaluation of the meeting

- Penetapan Perda APBD dan Peraturan Kepala Daerah tentang Penjabaran APBD or the legalization of the budgeting. 


\section{METHODS OF RESEARCH}

This study is a descriptive study that is done using the qualitative approach. This study was conducted in the Department of Regional Finance and Asset Management of Malang City, the House of Regiohnal Representatives of Malang City, and the Office of Expert Staffs in Economy and Finance of Malang City. The focus of this study included the performancebased budgeting, the indicators of the performance-based budgeting, and the factors that influence the implementation of the performance-based budgeting. The primary data of this study were obtained through interview, while the secondary data were collected from the document-review. The data were collected through observation, inteview and documentation. Whilst, the instruments used in this study were the researchers themselves as the key intruments, interview guide, and field notes. The obtained data were analyzed using the interactive analysis model proposed by Miles and Huberman which includes data condensation, data representation and the conclusion. The validity of the data was ensured by conducting the validity test, transferability test, dependability test and the confirmability test.

\section{DISCUSSION OF RESULTS}

The Process of Planning the APBD of Malang City. The yearly programs and actions are written in the Rencana Kerja Pemerintah Daerah (RKPD) or the Regional government Plan of the Yearly Programs. Based on the result of this study, some insights were obtained as follow.

The design of $R K P D$ has fulfilled the requirements of performance-based budget in which RKPD has three performance indicators that are used as the guideline in planning certain program.

The society has not yet intensively involved in the discussion. According to an informant, the musrenbag is not a pure discussion, but it is only a presentation of the information related to the program and any event that has been legalized by the village officers.

The conference on the plan of KUA from the regional government secretary to the Head of the district should have been conducted in the first week of June. However, in 2015 and 2016, the RKPD was done in July.

The arrangement of the budget was initiated from the KUA-PPAS up to the legalization of the $A P B D$. The data obtained in this study shows these following facts.

The arrangement of KUA-PPAS has fulfilled the requirement of the performance-based budget which has to be adjusted to the financial capability of a certain area.

The RKA-SKPD has been arranged in accordance with the guideline of the performance-based budget using the standard price per item and the standard general expenses.

As the winner of an award called Wajar Tanpa Pengecualian 5 year in a row from 2011 - 2015, Malang City always tries to complete the APBD on the scheduled time.

The arrangement of the budget was mainly dominated by the executives which made the legislatives as the representatives of the society had less role in controlling the trust from the society in the determination of the $A P B D$.

Malang City has started to implement the e-budgeting that makes it easier to plan certain budget based on the performance in which any program or event should be integrated into the computer-based system.

Parameters of the Implementation of Performance-Based Budgeting in Malang City. The standard of minimum service is important to make sure that each SKPD gives proper service based on the standard operational procedure. Besides, it also prevents inequality of the services from occurring in certain areas. The arrangement and the legalization of this parameter is ruled in the Government Regulation Number 65 or 2005 on the Guidelines of the Arrangement and Legalization of the Standard of Minimum Service. The government of Malang city always makes sure that each SKPD fulfills the minimum requirements. This has 
been confirmed through an interview with Mr. Prasetya Petandra who was the staff of the division of program planning in Kantor Badan Perencanaan, Penelitan dan Pengembangan Kota Malang on October $5^{\text {th }} 2014$ at 14.45 , in which he stated that,

"To the best of my knowledge, barenlitbang has all the data needed. All of SKPD in Malang has fulfilled the SPM".

Standard price per item is used in the arrangement of KUA-PPAS, DPA, and RKA$S K P D$. The fluctuation of the price demands the $S S H$ to always update the data every year. In Malang city, $S S H$ is legalized by the Regulation of the City Governor of Malang Number 41 of 2014 about the standard of per item price in 2015. The price includes: Standard of honoranium; Standard of overtime work wage; Standard business trip funding; Standard wages and goods; Standard rental cost; Standard price of consultation or billing rate; Standard honoranium and other components.

Malang City as the awardee of Wajar Tanpa Pengecualian (WTP) award 5 year in a row has not yet owned any analysis of standard expense out of the four indicators. As the consequence, the fairness of the work expense and the fund needed for a program or an event cannot be pricesely measured. This appears as a weakness that might trigger some individuals to mark up the budget.

Performance indicators are made to ensure that the goals and the target of certain programs or events held by the regional government measureable. The performance indicators of Malang City is written in the Regulation of the Malang City Government number 30 of 2015 on the completion of the performance indicators of Malang in 2015. Mr. Prasetya Husada who is a staff in the division of program planning in Kantor Badan Perencanaan, Penelitian dan Pengembangan Kota Malang stated in an interview held on Octover $5^{\text {th }} 2017$ at 14.45 that "Performance indicators were created by barenlitbang during the arrangement of the RKPD".

Factors that Influence the Planning of Performance Budget in Maang City. From the result of the interview, it can be seen that discussions, conferences, and meetings are the crucial steps in makin certain decisions. Even more, results of meetings during the planning of performance-based budgeting were written in agreement notes. It is a matter of fact that no one is perfect, and no matter how good the leaders are, they would not be able to lead the leadership themselves. Thus, a good cooperation from all of the elements in Malang city is needed for the success of the financial management reformation especially the planning of performance budget in Malang city.

In addition to the social factor, organizational factor also has a significant influence to the success of the financial reformation. A completely different change would be difficult to happen if certain attitude within the organizational culture is too strong. This case also occurs in the planning of the performance budget in Malang city. As a nation, regional government must still obey the rules of the central government.

Well-developed countries spend high proportion of their national budget for the society, while developing countries tend to give smaller proportion of the budget for the society. The results of several interviews point out the fact that the fulfillment of the high amount of direct transactions caused lesser proportion of the national budget for the society. Even more, within the budget for indirect transactions, there has been a huge amount that should be spent for officers' necessities although the informants were fully aware and had huge expectation that the budget of Malang city should be mostly spent for the society. It is an unfortunate that the regulation prevents it from being implemented.

The reformation of the local financial management demands contributions from various parties. One of the major challenges in implementing this plan is the planning step of the performance budget. Based on the interview, it is stated that the political condition has a major role in the success of performance budget implementation. In this case, supports from the government, non-government parties and the society are necessary during the planning step. The government also has an optimistic belief that good governance can be achieved by implementing the performance-based budgeting.

Human resource is the key to the success of the planning step, which determines the following steps. Therefore, high quality human resources who understand the planning step 
guarantee the success of regional development. On the contrary, low quality human resources inhibit the process of regional development.

Some changes should be made to reform the financial management of regional government. One of which is by implementing the performance-budget system, replacing the old traditional budgeting system. The planning step of performance budgeting requires some programs and actions from SKPD that do not only give good output but also good outcome. Besides, this plan also demands good integration of programs and actions held by the regional government. Hence, there should be no more programs or actions that are arranged out of sudden.

Information and technology are influential to the reformation of the regional financial development. However, some informants believed that the advancement of information appeared as obstacles in the implementation of the performance budgeting system. This understanding is related to the frequent modification on the regulations which is found to be problematic for the planners to keep adjusted to the newest system. Fortunately, the government provides trainings, workshops, and socialization on the current regulation to be implemented by the government of Malang city.

Different from the advancement of information, advancement of technology is considered helpful in the planning of the performance budget. One of the major change that utilizes the advancement of technology is the implementation of e-Budgeting that allows the arrangement of RKPD, KUA-PPAS, RKA, RAPBD, DPA up to the accountability report to be done within the integrated system. E-Budgeting clearly simplifies the implementation of performance budget for it integrates various procedures in the planning step.

Any kinds of regional development are strongly related to the use of the regional budget. Those two different elements should synergize to create a feasible way to implement the program. If the regional budget is enough to fund regional programs, regional development can be accelerated. On the contrary, if the regional budget cannot afford the expenses for conducting certain programs, the regional development might be obstructed. Therefore, funding is an absolute requirement for the implementation of the performance budgeting system.

\section{CONCLUSION}

From the resulf of this study on the planning of performance-based budgeting as an attempt to reform the financial management of Malang city, it can be concluded that the planning step has been done on time. However, late fund distribution from the central government inhibit the implementation of this program. The governemnt of Malang city also has made some attempts to create an integrated budgeting system although some new programs occurred out of the plan.

In relation to the implementation of performance budgeting system, the government of Malang city utilizes 3 (three) tools to ensure the success of the program. The tools include the Standar Pelayanan Minimal (SPM) or the minimum standard service, Standar Satuan Harga $(S S H)$ or the standard price per item and Indikator Kinerja (IK) or the indicator of performance.

Meanwhile, factors that influence the planning of the performance-based budgeting involve the environmental factor of the regional government of Malang city including the social factor such as discussions and conferences, organizational culture, the condition of the economy, and the regional leadership. On the other side, the officers have been considered eligible to pefrom their jobs, even though only some of them understand accounting. In conclusion, Malang city has been successfully implemented the performacebased budgeting system even though the regulations are frequently changing. The success of the implementation of performance-based budgeting system is also influenced by the advancement of information, technology, and strong funding. 


\section{REFERENCES}

1. Bryant, Coralie dan Louise G. White. 1982. Managing Development in the Third World. Peter Hagul (editor), 1982. First Edition, Westview Press. Inc. Rusyanto L Simatupang (penerjemah). 1987. Manajemen Pembangunan untuk Negara Berkembang. Edisi Pertama. Jakarta: LP3ES.

2. Halim, Abdul, 2007. Akutansi Sektor Publik. Jakarta: Salemba Empat.

3. Nordiawan, Deddi, 2009. Akutansi Sektor Publik. Jakarta: Penerbit Salemba Empat.

4. Rahayu, Sri. 2007. Menyibak Proses Penyusunan Anggaran Pemerintah Daerah (Studi Fenomenologi pada Satu SKPD di Provinsi Jambi). Thesis Universitas Brawijaya Malang.

5. Riyadi dan Deddy Supriady Bratakusuma, 2003. Perencanaan Pembangunan Daerah: Strategi Menggali Potensi dalam Mewujudkan Otonomi Daerah. Jakarta: PT. Gramedia Pustaka Utama.

6. Siagian, Sondang P. 1978. Administrasi Pembangunan. Jakarta: PT. Gunung Agung, Jakarta.

7. Subekan, Achmad, dan Nafsi Hartoyo. 2012. Keuangan Daerah: Terapi Atasi Kemiskinan. Malang: Dioma.

8. Suhadak dan Trilaksono Nugroho, 2007. Paradigma Baru Pengelolaan Keuangan Daerah dalam Penyusunan APBD di Era Otonomi. Malang: Kerjasama Lembaga Penerbitan dan Dokumentasi FIA-Unibra dengan Bayumedia Publishing.

9. Tjandra, W Riawan. 2006. Hukum Keuangan Negara. Jakarta: Grasindo. 